\title{
Exploring marine spatial planning education: challenges in structuring transdisciplinarity
}

\begin{abstract}
Marine Spatial Planning (MSP) has experienced vigorous growth on the international scale in recent years, and several practices has emerged from different countries. The demand for specific training in the preparation and implementation of marine planning has therefore already shown itself to be quite relevant on a global scale. Educational initiatives related to MSP have to respond to the increased complexity of MSP, which integrates environmental and economic perspectives on marine resources and maritime sectors, considering governance framework as well as maritime affairs and legislation. This paper aims at addressing the educational and training needs for the development of both academic education and professional training in MSP. Learning skills, contents and methods of an 'ideal' MSP course are depicted from widely accepted operative guides on MSP and from the EU Framework Directive on MSP (2014/89/EU). They are considered for the analysis of the current educational offer around MSP, performed in a sample of countries that have already undergone a process of implementation of MSP by Law. As result, beside the great variety of courses, it emerges that MSP education seems to be often regarded from an environmental perspective - in continuity with Integrated Coastal Management education - while planning theory and experiences in MSP are the least represented contents. Results are discussed in relation to three major challenges: i) how educational offer reflects on transdisciplinarity, ii) the role of theory in MSP courses, and iii) the enforceability of Plans as major concern in MSP.
\end{abstract}

\section{Keywords}

Marine Spatial Planning, education, training, transdisciplinary, theory

This is the accepted manuscript of a paper originally published in Marine Policy. You may find the final, formatted version at 10.1016/j.marpol.2016.09.016. 


\section{Introduction}

Marine Spatial Planning ${ }^{1}$ has experienced vigorous growth on the international scale in recent years. Prior cases can be observed in initiatives at the end of the last century, with reference to the cases of Canada and Australia [1]. One of the best known plans, the Rhode Island Ocean Special Area Management Plan (SAMP), was passed in 2011 [3], and the general regulations that compel all European Union (EU) Member States (MS) to prepare maritime spatial plans (Directive 2014/89/EU, [4]) has just begun its process of legal implementation (transposition into respective national law). This must be concluded before 18 September 2016, and plans passed by 31 March 2021. What began as a concern of developed countries is now on the agenda of developing countries and included in the activity programmes of different international organizations. The so-called "BRIC" countries (Brazil, Russia, India, China) were among the earliest States to formulate new marine policies, although they did not develop planning instruments at the same time $[5,6]$. Also, the lists of countries with marine spatial planning initiatives $[2,7,8]$ is expanding with the inclusion of developing countries, and institutions such as IOCUNESCO itself, FAO and UNEP have already included marine spatial planning in their training programmes [9]. The demand for specific training in the preparation and implementation of marine planning has therefore already shown itself to be quite significant on a global scale.

While it is true that, as a tool for integrated action, the planning of marine space is only now acquiring the same legal rank as spatial planning on land - except for the differences in areas -, the management of activities and uses in the marine environment already has a long track record on both the national and international scales, particularly in sectors such as shipping and fishing. Studies and training related to the maritime economy sector set and under the general name of 'maritime affairs' have been incorporated into academia during recent decades, albeit with a range of orientations giving priority either to specific sectors, such as logistics and maritime transport, or to legal questions linked to the new codification of the law of the sea, whose period of institutional development (Third United Nations Conference on the Law of the Sea, 1973-1982) coincided with the increase in the most notable initiatives in the academic world. A 1982 United States educational administration working document [10] states the need to design integrated education in relation to the marine and aquatic environment (sic) that incorporates the social sciences and the humanities. The University of Rhode Island's Department of Marine Affairs has offered Master's programmes since 1969 [11]. The present-day Gerard J. Mangones Center for Marine Policy (University of Delaware) was created in 1973 and its current first-degree programme includes marine spatial planning [12]. Cardiff University is transport linked and currently offers two MSc degrees related to this sector and an MSc in Marine Policy. In Canada, the University of Dalhousie is home to the International Ocean Institute, founded in 1972 by Elisabeth Mann Borgese, who became professor in maritime affairs in 1979 [13].

The current development of marine spatial planning is not only the result of marine policy studies that, as stated above, became the focus of growing interest from the late 1960s, but also takes these as its general framework. It is clearly linked to the management of coastal zones (ICM) which, under various names (to stress the need for its integrated

\footnotetext{
1 Marine Spatial Planning is the term used internationally in both academic literature and technical documents. Inside the European Union, however, the expression "maritime spatial planning" is used in official documents, more for the distribution of competences within the institution than for technical or academic reasons. Other expressions variously used are "offshore spatial planning" and "coastal and marine spatial development plan" [1].
} 
implementation) has become markedly instrumental in nature, the responsibility for which has been taken, at least nominally, by the vast majority of the national and regional administrations around the world ${ }^{2}$. It is rare for any international organization not to have taken any initiative with regard to the management of coastal zones [15-21], including the European Union [22], which, after a long process ${ }^{3}$, begun in 1973 (Council of Europe) and with heterogeneous results, has culminated in the recent adoption of Directive 2014/89/EU Maritime Spatial Planning.

This is, therefore, a longstanding process constructed through a series of phases which, over time (at least four decades), has gradually acquired not only conceptual complexity - from sustainable development [23] to Ecosystem Based Management [24] - but, at the same time, a greater territorial dimension, with current marine spatial planning also including areas under national jurisdiction (including the exclusive economic zone and the continental shelf beyond 200 nautical miles), although there has also been growing international interest in marine Areas situated Beyond National Jurisdiction (ABNJ). Based on Resolution 68/70 of the United Nations General Assembly three meetings were called of the Ad Hoc Open-ended informal Working Group "to study issues relating to the conservation and sustainable use of marine biological diversity beyond areas of national jurisdiction" [25].

New educational initiatives worldwide have to respond to this increased complexity of coastal-marine planning - under its current name of marine spatial planning - by i) delving further into the transdisciplinary approach that began to be adopted at the beginning of this process, and ii) including the successive environmental-(ecosystem based management) and economics-based (blue growth) focuses that dominate the present approach to marine planning (especially in EU with the MSP Directive [4]).At the same time, territorial planning techniques (from zoning to the vast body of planning, management and implementation tools) need to be developed in maritime space, a veritable leitmotif of the emerging generation of plans.

This paper aims to address the educational and training needs for the development of both expertise and professional practice in MSP. The analysis is based on two main aspects: i) the identification of key characteristics of MSP according to the review of widely accepted operative guides on MSP implementation and the Directive 2014/89/EU [4], as criteria upon which training and educational targets should reflect; ii) analysis of the educational offer in relation to MSP in the countries which have undergone a process on MSP for their maritime domains, with a specific focus on EU.

Results are discussed in relation to the challenges arising from the transdisciplinary nature of MSP, a key emerging aspect, as well as in relation to the elaboration of an MSP 'theory' that reflects on the enforceability of MSplan. Gaps and requirements are identified to pave the way for the implementation of education in MSP, with regard to the possible identification of MSP as a discipline.

\section{Materials and Method}

\subsection{Key characteristics of MSP}

\footnotetext{
${ }^{2}$ The pioneering work by Biliana Cicin Sain [14] sponsored by the Center for the Study of Marine Policy (University of Delaware) and UNESCO-IOC is a broad dissemination of the coastal zone planning initiatives of the time.

${ }^{3}$ The http://ec.europa.eu/environment/iczm/background.htm [accessed 18.08.2015] website offers a complete synthesis of the history of [ICM] from 1973 to the present day.
} 
In order to understand the educational and training needs for the development of expertise and professional practice in MSP, but also to lay the foundations for MSP as a discipline in academia, the research identifies the key characteristics of the MSP process in order to identify i) the contents of an 'ideal' MSP educational course, in terms of knowledge, theory, and applied knowledge that the educational programme should consider, and ii) the methods and tools behind an MSP process, as suggested by Davoudi \& Strange [26] when analyzing terrestrial spatial planning.

This research considers key aspects of MSP that emerge from the existing leading documents elaborated respectively by UNEP [27] and by UNESCO [28]. Both sources base their elaborations on the analysis of existing case studies of MSP around the world, in order to underline the importance of learning from the experiences and to acknowledge challenges arising from experiences recollected and discussed with planners, practitioners, and with decision makers involved in the process. Moreover, they represent the perspective of the two international Oorganizations (UNESCO, UNEP) which have supported and informed MSP in its scientific and theoretical background as well as in its actual implementation around the world. The analysis also includes indications deriving from the Directive 2014/89/EU establishing a framework for maritime spatial planning in the European Union [4], as the guiding legislative source for the harmonized implementation of MSP in EU marine waters. The key aspects emerging from the analysis are reported in tab. 1.

\section{Table 1 here}

Considering the proposed framework, different types of skills and expertise are necessary to establish and to carry out an MSP process. One key challenge is related to the knowledge skills required in consideration of the variety of planning process content material (analytical and applied knowledge). On the one hand, knowledge skills on marine environmental dynamics, changes and impacts are required in order to gather "sufficient high-quality data and data collection capacity" [27, p9]for e purposes of MSP. On the other hand, knowledge skills on maritime affairs and international legislation are also required in order to consider the enforceability of measures and actions resulting from an MSP process, as well as to support the establishment of an MSP process based on feasible context-based "governance arrangements" [27, p18]. Other skills are related to the capacity to adopt a strategic thinking, to articulate MSP process clearly, from the "agenda setting" to "problem solving". MSP entails the "executive decision making and prioritization in conflict resolution (...) [as well as the] development of unambiguous goals" [27, p19] within a transparent and shared structure based on "shared vision, goals and objectives" [27, p17]. Other fields of expertise are related to methods and tools to support the process implementation, concerning both data management and analysis (as GIS or DSS), and stakeholders engagement, a key "enabling factor for MSP success, and even more so for the transition to implementations" [27, p20]. Communication and learning skills are deemed, in terms of "transparency, trust-building and credibility" [27, p22], to be recurrent key elements in establishing and developing stakeholders engagement.

The major challenge in building an MSP process framework is to put the key principles into practice, considering the particular conditions and settings of the different case studies. Difficulties and barriers encountered duringMSP process and implementation be politically motivated; in this paper we discuss the capacities and skills required for MSP. An emerging urgent issue in implementing an effective MSP process is to establish a well-designed MSP process since the pre-planning phase [27, 28], as "the preparation 
phase of the process contains the greatest number of enabling factors for implementation success" [27, p23]. Ideally, the proponent and the planning team should i) have the technical expertise on MSP contents and methods, ii) be aware of the key principles of MSP, iii) apply this knowledge critically on pilot cases. These represent the basic skills required in order to structure a tailored MSP process. However, the lack of the technical expertise at both local and national levels is considered to be an issue that requires urgent attention[27], as it can be a serious hurdle to achieving effective MSP processes and objectives. The key characteristics of MSP adopted as educational needs in this paper correspond to those emerging from the analysis of Glegg [29], for the identification of the key components of MSP training for professional development.

The next section reports the sampling method for the analysis of current educational provisions relative to MSP.

\subsection{Analysis of current educational provision}

The analysis of the current educational provision focused on European Member States that have already undergone a process of MSP in marine waters under their jurisdiction (tab. 2). For these countries, Marine Spatial Plans have been passed under a process of elaboration and negotiation with different parties and stakeholders. They have been approved and enforced under specific national legislations and they are currently under implementation. In the European Union,Belgium, Germany, The Netherlands, Portugal and theUK have been selected.

\section{Table 2 here}

Moreover, other countries and states have been added because of their pioneering and prominent role in MSP elaboration and implementation, as well as their recognized role in the provision of education, such as i) HELCOM countries; ii) Norway; iii) Australia, iv) State of Rhode Island, v) Commonwealth of Massachusetts. Countries under the Convention on the Protection of the Marine Environment of the Baltic Sea Area, known as the Helsinki Convention (HELCOM), signed in 1992, have been taken into consideration: Denmark, Estonia, Finland, Germany, Latvia, Lithuania, Poland, Russia and Sweden. Norway has been considered for the ongoing MSP processes in Atlantic and Artic regions, and for the ancestral tradition in maritime affairs and economy [40]. Australia has been selected because the Great Barrier Reef Marine Park, one of the earliest and well-known examples of MSP in the world, has already undergone several MSP revisions and implementation [38,41]. For the United States, the States of Rhode Island and Commonwealth of Massachusetts have been selected, as their plans have formally completed elaboration and have since been enforced in the two states.

Analysis of the current educational provision has been developed for each country and state, considering principally i) formal education delivered by Higher Educational Institutions (HEI, i.e. Universities) as Bachelor/undergraduate (BUG), Master/graduate courses (MG); ii) informal education, as training, life-long-learning courses or courses for professionals delivered by other Bodies, such as professional associations. $\mathrm{PhD}$ programmes have not been included in the analysis. Many institutions offer opportunities for PhDs but without a formal program; their contribution cannot be fully determined with this methodology. Individual modules or units related to MSP within programmes on other topics have not been taken into consideration in this analysis, which considers 
self-standing courses that focus on MSP, as planning, governance and management of marine spaces as key topics.

A first investigation consisted of identifying existing courses on MSP, through the internet searches using key words as "marine spatial planning" and "maritime spatial planning", including words referring to the educational sector, such as "course", "training", "master", "program", "university", "education". This first analysis resulted in the identification of informal educational courses and the primary identification of formal educational courses.. As a second investigation, searches were made for the provision of MSP-related education on educational portals in Europe in general ${ }^{4}$, or for specific countries $^{5}$. Moreover, the analysis considered educational provision identified on portals devoted to marine and coastal affairs ${ }^{6}$. A third investigation consisted of considering the educational provision of individual Universities, starting from the list of universities per country taken from Wikipedia ${ }^{7}$, considering those that include sectors related to marine and coastal science in general.

In all three investigations, key words such as "marine spatial planning" and "maritime spatial planning" were adopted, then the key words "marine", "ocean", "coastal", "planning", "management", "governance" were entered separately and in combination. The search was carried out in English as well as in the national languages of the different countries. The keywords "ecosystem based management" and "ecosystem based approach" were not adopted in the initial phase of identifying courses, as the investigation is focused on courses which are deliberately devoted to the strategic proactive activity of planning marine spaces and activities entailed in MSP [28], based on analytical activities related to multiple and interdisciplinary topics.

An initial list of courses was compiled, combining the information from the three activities $^{8}$. Then, each course was analyzed according to the criteria identified in par. 2.1 tab. 1 for i) contents, ii) methods, and with respect to iii) organizational issues (such as certification and level, duration and frequency, delivery language, internship periods, admission process and institutional arrangements), through the textual analysis of the course description, of syllabuses of the modules, as well as all the information available on the course websites.

After analysis using the criteria defined above, some courses were discarded based on their content analysis, such as i) those which focus only on environmental analysis without considering planning and management; ii) those which concentrate only on the planning and management of only one sector (for example, management of coastal and aquatic resources; or those related to aquaculture and fishery management). With regard to those related to coastal areas, we discarded the ones that do not explicitly include any marine reference or issue. Programmes related to marine science and geoscience, as well as marine biology and ecology were also discarded.

The results of the analyses were then summerized in one single database that contains the different educational courses offered. A text analysis on course titles was performed to

\footnotetext{
${ }^{4}$ E.g. www.postgrad.com, www.findamaster.com, www.mastersportal.eu [accessed 05.01.2016]

${ }^{5}$ E.g. for Australia www.hotcourses.com.au/australia/masters-courses-australia/pg.html, for Germany www.daad.de/deutschland/nach-deutschland/angebote/en/12068-finding-the-right-course/ or for the UK www.thecompleteuniversityguide.co.uk/, [accessed 05.01.2016].

${ }^{6}$ E.g. the Euromarine training catalogue, www.euromarineconsortium.eu/content-education/overviewtrainings; Marine training network http://www.marinetraining.eu/content/adopted; the European Thematic Network in the field of aquaculture, fisheries and aquatic resources management, which hosts an educational database and related map, http://www.aquatnet.django.io, [accessed 05.01.2016].

${ }^{7}$ www.wikipedia.org [accessed 01.03.2016].

${ }^{8}$ The complete list of courses was finalised on 06.11.15.
} 
understand the focus and the perspectives adopted by different programmes. Then, descriptive statistics on course level and type and on organizational issues were recorded. Analysis of educational provision with respect to contents and methods criteria was performed i) for the entire educational provision, ii) per course type and iii) per country in which there are 4 or more courses.

\section{Results}

Analysis of the educational provision identified 51 courses related to marine spatial planning (tab. 3), out of an initial panel of 191 courses delivered by 137 HEI and other 13 organizations within the sample countries selected for the analysis (tabs. A1 and A2) (at 06.11.15).

\section{Table 3 here}

\subsection{Analysis of the Courses' denominations}

With respect to the analysis of the titles of the different programmes (tab. 4), only 6 programmes out of 51 (11.8\%) refers to "Marine Spatial Planning", and only $3(5.9 \%)$ to "Maritime Spatial Planning", which has been adopted by the Framework Directive on Maritime Spatial Planning (2014/89/EU). The percentage of programmes that refer to "Marine science" is higher $(23.5 \%, 12$ programmes $)$. With respect to single words related to the field of action of the programmes, "management" is present in $37.3 \%$ of programme titles, while "planning" in just $25.5 \%$, on a par with "science/studies". "Environmental/ecology" is cited in $15.7 \%$ of cases, while "natural resources/resources" and "policy" are found in just $7.4 \%$ each, and "governance" is quoted in just 2 programmes $(3.7 \%)$. With respect to spatial focus, with $56.9 \%$, "marine" is the most represented word, followed by "coastal" at $21.6 \%$, while "maritime" is present only in $11.8 \%$ of programmes. It is interesting to note that only 8 programmes $(15.7 \%)$ make explicit reference to the "spatial" dimension entailed in MSP.

\section{Table 4 here}

\subsection{Level}

Among the courses, the vast majority (33 courses, 64.7\%) are Master/Graduate programme level(MGP), while a 27.5\% (14) are training courses (TC). Bachelor/undergraduate programmes (BUGP) are very limited in number (4 courses; $7.8 \%$ ). Out of the 4 BUGP, only one belongs to an European Country, Finland, while the others 3 are delivered in Australia (2) and in Massachusetts (US, 1). Because of the very limited statistical significance, analysis of the results focuses only on the other two types of courses, namely MGP and TC, while general characteristics of courses are recorded in tab. 5 where BUGP and MGP are considered together under "Education" offer.

MGP are the most important type of courses provided around MSP, equally distributed among sample countries. Only Latvia, Finland and Poland do not deliver any master/graduate programmes related to MSP, while in the UK 9 Universities offer master programmes specifically focused on MSP, plus other 3 training programmes. 


\section{Table 5 here}

\subsection{Organizational issues}

Almost the $90 \%$ of courses are organized and delivered by universities (Higher Educational Institutions, HEI) (tab. 5). The percentage changes in the case of TC, where the responsibility of Research organizations (RO) and International Organizations (IO) is higher (almost 45\%) (fig. 3). Within the courses, almost 40\% are delivered in partnership, with a higher percentage for TC $(64,3 \%)$ (tab. 5).

TC can be classified according to the participants they target, differentiating between educational courses or training course related to lifelong learning programmes (tab.6). The majority of courses are intended for professionals, and several admit a mix of professionals, scientists and students (mainly $\mathrm{PhD}$ and graduates).

\section{Table 6 here}

While the entry level is related to the type of programme (except for TC), analysis of the entry requirements of the programmes in relation to the candidates backgrounds and fields of study (tab. 6) shows results as follows. As far as concerns MGP, a total of almost 30\% are related to Marine Science (environmental) (MS) and Marine and Coastal Engineering (MCE), only one Master admits exclusively students with a background in Social Sciences and Humanities (SSH), while only the $45.5 \%$ considers students with backgrounds from multiple sectors, including SSH and MS and MCE. With respect to the $\mathrm{TC}$, a vast majority of courses are open to professionals, followed by scientists and finally students (graduates and $\mathrm{PhD}$ ). Considering the background entry requirements (tab. 6), $63.2 \%$ of courses (9) are open to candidates with different backgrounds (SSH, MS and $\mathrm{MCE}$ ). For the other 5, there is no specification of background, but given that 4 out of 5 are open to participants of different levels (professionals, scientists and students), it is reasonable to expect that they also accept different types of educational background.

Finally, as far as internship within study programmes are concerned, only 10 courses (19.6\%) out of 51 expressly mention a period of internship as part of the student carrier, of which 8 are of Master/graduate programmes (24.2\%), 1 is a bachelor and 1 is a training course.

\subsection{Contents and methods}

With respect to contents (knowledge and theory, fig. 1a), for all courses typologies, that seen most frequently is "environmental analysis/assessment", which is present in $87 \%$ of the overall sample of courses. The least represented categories are "planning theory" (only $31.5 \%$ ) and "experiences in MSP" (37\%). With respect to the relevant tools and methods for MSP (fig. 1b), "spatial tools" as GIS and methodologies to develop "applied knowledge" are well represented in the entire sample, with respectively $83.3 \%$ and $87 \%$ respectively of the 51 courses. The least represented is the "stakeholders involvement" category, with just $55.1 \%$, which means that one course out of two does not explicitly mention "stakeholder engagement".

\section{Figure 1 here}


Considering the courses types, the six content characteristics of MSP are revealed to be unbalanced in the educational programmes (TC, BUG), which are more oriented towards environmental analysis and assessment topics, with "Planning Theory", "Experiences in MSP" and "Maritime Affairs/domain" the least represented. In contrast, the course content is more balanced in TC, which explicitly target MSP. However, "planning theory" is less considered in TC, which are more practice-oriented.

With respect to tools and methods, "stakeholder engagement" is generally underrepresented in all types of course, where "spatial tools" and "applied knowledge" are almost the same frequency (fig. 1b).

If the analysis of contents and tools is performed for the case studies with more than 4 courses (Belgium, Finland, Germany, Norway, UK, Australia), different sets of characteristics can be identified, which prove a different approach to the provision of education on MSP (fig. 2 and 3). While for courses delivered in Australia more relevance is given to "environmental analysis and assessment" with respect to "maritime affairs" and "maritime sectors", in the UK there is a balanced presence of the three subjects. In Germany and Norway the study combination of "environmental analysis and assessment" with "maritime sectors" is clearly dominant. Only the courses delivered in Finland show a more balanced presence of all 6 of the content components. With regard to methods and tools (fig. 3), the 3 components are never all equally represented; "stakeholder engagement" is generally under-represented in Belgium, Germany, Norway, UK and Australia, while for Finland "spatial tools" are not explicitly mentioned.

Finally, the only courses where all the content, tools and methods are equally represented are those in the State of Rhode Island, US, reflecting reflection of the depth of experience of studies in Maritime Affairs.

\section{Figure 2 here}

\section{Figure 3 here}

\section{Discussion}

From the analysis of educational programmes related to the field of MSP, current emerging characteristics in MSP education and training can be highlighted, including possible issues and gaps that need to be tackled in the future. Major efforts in education on ICM [42-45] and on marine conservation [46-48] are reported in literature. This study constitutes a first attempt to depict trends in education and training in MSP, which are discussed in relation to three major issues: i) how the educational provision reflects the transdisciplinary nature of MSP, ii) the role of theory in MSP courses, and iii) the enforceability of Plans as a major concern in MSP.

This analysis not only considers continuing professional education, as discussed by Glegg [29] for the UK, but also tertiary education and programmes (namely higher education), to propose a theoretical reflection on academic requirements and the fundamentals of MSP as a transdisciplinary subject. Recently, the terms interdisciplinarity, multidisciplinarity and transdisciplinarity have seemingly been used interchangeably, even if entailing different concepts [49]. In a transdisciplinary framework, researchers and experts overcome disciplinary boundaries to establish, dismantle and define solutions jointly for a specific shared problem [48], integrating knowledge from different 
disciplines under a unified framework towards a common vision [49]. MSP has been assigned the role of transdisciplinary subject [28, 48, 50], as MSP processes deal with resource management problems including resource economics, welfare economics, and institutional analysis [49], confirmed by the analysis of tab. 2. Some problematic issues in grasping the transdisciplinary nature of MSP emerge from the analysis of the current educational provision, specifically in relation to the level and types of programmes and to the analysis of the articulation of contents and methods.

With respect to the course level, in European countries within the sample, MSP is mostly part of academic education in postgraduate programmes (Master), or of training programmes regarding life-long learning. Given that the planning and management of maritime spaces entail the capacity to operate within multiple disciplines and applied skills, BUGs related to MSP are limited, and some insight is given in specific courses within the curricula ${ }^{9}$. BUGs are revealed to provide basic knowledge and skills mainly on disciplinary domains, grounded in a core discipline [47, 51] such as ecology, oceanography or law.

The issue of integratory and transdisciplinary nature of MSP is only partially covered in the educational courses considered in this paper. This point demonstrates the challenge of establishing higher educational programmes [46]. On the one hand, the transdisciplinary nature of MSP costitutes the acquisition of important learning skills for graduate students [48]; on the other, the methods and effectiveness of delivering balanced programmes both in disciplinary knowledge and applied skills [47] are not yet agreed [48]. Blickley et al. [47] report on the importance of anticipating key learning topics at graduate level as a strategic action for professional success. However, analysis of the entry level for MG programmes demonstrates the reduced presence of students with different backgrounds within the same programme, which are still very disciplineoriented. Until today, there has been a "preponderance of natural scientists interested in marine management and pointed to a need for a wider skill set" [29, p15]. Even if exchange and integration between students of different backgrounds is deemed valuable to proactively promoting integration and transdisciplinary learning skills [29], our findings reveals that this is not reflected as a dominant characteristic in educational offer related to MSP.

This aspect also emerges from analysis of the content of programmes related to MSP; there is a clear dominance of contents related to "environmental analysis/assessment" and "maritime uses", while the least represented are "Experiences in MSP" and "Planning theory". This can be explained in several ways: firstly, it seems that courses related to MSP are in continuity with education in ICM, where ecological science, applied geography and physical science are the most emphasized theoretical subjects, along with assessment and monitoring, as reported in the analysis of educational offer in ICZM of Garriga and Losada [45]; secondly, environmental studies and marine science have a long tradition in managing marine resources from the perspective of conservation. Marine conservation planning, which originates from the key concept of biodiversity protection, often resolved in the implementation of Marine Protected areas [among others, 52-54], is shifting its perspective towards marine spatial planning $[55,56]$. This is visible, for example, from the evolution of the software MARXAN [57]. Originally designed for

\footnotetext{
${ }^{9}$ For example, at the University of Turku (Finland), the course on Energy, Shipping and Sustainable Development in the Baltic Sea Region", (0-5 ECTS), which explicitly mentions MSP, is included in the BSRS Baltic Sea Region Studies, especially addressed for both undergraduate and graduate exchange students; https://nettiopsu.utu.fi/opas/opintoKokonaisuus.htm?rid=20336\&uiLang=en\&lang=en\&lvv=2015, [accessed 01.03.2016].
} 
solving complex conservation planning problems in landscapes and seascapes [58-60], it has been improved to ensure that a variety of conservation and land- and sea-use objectives are achieved while minimizing costs of a zoning plan [60,61], expanding in practice "on the basic reserve design problem to allow for zones" [60, p1514], considering that, MARXAN was unable to deal with a range of management actions further to conservation in its original version [62].

It can be affirmed that existing courses appear as a re-orientation of already established programmes (and related approaches) towards new questions and demands inherent to MSP, instead of being established to cover specific areas of MSP, except for some training courses and for the programmes in which content and methods are balanced in the composition of the educational provision (only 8 out of 51).

The spatial dimension entailed in MSP is not explicitly considered in the large majority of educational programmes, not even mentioned in programme titles, as emerging from our results. The spatial dimension is usually put in practice through zoning, being a key action often involved in MSP [63, 64], aiming towards spatially and temporally designating areas for specific purposes [60], areas through which maritime uses are allocated spatially $[28,64]$. The apparent gap in spatial dimension can be interpreted from the fact that 'planning the sea' is only a recent feature in regulations (the EU framework directive was outlined in September 2014) even though various plans were established earlier (such as Rhode Island of 2010), and "marine planning is being introduced from almost a zero baseline, in the way land planning was not" [29, p13].

It is interesting and astonishing to notice that, besides zoning, none of the national laws of the countries in our sample clearly establishes specific mechanisms and enforcement requirements to be applied in Maritime Spatial Plans, but only design a general framework under which MSP processes are implemented. Even the Directive 2014/89/EU [4] identifies the so-called "minimum requirements" that each plan should include (art. 6). This is reflected in MSP education, where no "planning theory" is considered because no theory has been yet elaborated, formalized and shared with respect to rules and regulations defining mechanisms and tools to enforce planning decisions and zoning. In terrestrial planning legislative frameworks include details on content, procurement, duties and rights as well as mechanisms of compensation and enforcement of plans, as operational tools enforced by law [65]. In MSP these aspects are decided upon application, except for the UK and its Marine and Coastal Access Act (2009) [66]. The lack of a system of implementation rules and tools can constitute a vast field of experimentation and potential advancements for developing MSP theory, to be acknowledged as a specific topic of education in MSP. On the other hand, it leaves open an issue, which already emerged in ICM. In principle, MSP was conceived as a process to coordinate maritime sectors - as emerging from legislative framework [4] and from literature $[28,67]$ - that are independently governed according to established laws and regulations. The problem of enforceability of marine plans is not yet developed and codified, and it is currently left to the voluntary cooperation of administrative sectors and departments - as subjects of certain administrative power - strongly influenced by the culture of administrative cooperation that each country has built up over time. . For example, the Netherlands has a long tradition in administrative cooperation between sectors. This is witnessed by the experience of the Interdepartmental Coordinating Committee for North Sea Affairs (ICONA), that, as far back as 1992, issued the North Sea Atlas for Netherlands policy and management [68] from the cooperation of several Dutch Ministries. In the UK the MCAA (2009) was designed and enforced to "replace a fragmented, ad hoc, and bureaucratic process of marine management with a strategic, integrated, and centralized system" [66, p96]. However, the effectiveness of the MCAA 
has been disputed by Boyes and Elliot [69], because of limits and barriers in its implementation in practice. These actions may have contributed to the fact that the Netherlands and the UK are currently among the pioneer countries in Europe in the implementation of MSP. Cooperation is also complicated in MSP - more intensely than in ICM - by the fact that marine waters (National, Exclusive Economic Zones and High Seas) involve different international, national and local levels of governance $[5,70]$.

As a consequence, a great variety of courses find their space between different experiences and legislative paths developed in each country, and only in some cases educational offer in MSP seems to follow the culture of implementation and acknowledgement of MSP elaborated individual countries. The educational provision in the UK seems to be the best established, according to the number of courses, but also to the topics, in line with the great effort put in by the government in the implementation of MSP at national level, as a tool to plan and manage maritime waters within the Exclusive Economic Zones [66]. With the MCAA the government has also created the Marine Management Organization, a body devoted to manage maritime spaces, and specifically to elaborate MSP and related environmental appraisal [29, 66]. Another important case is Australia, where several courses are offered, mostly on marine and coastal management. In this case, the experience gained with the Great Barrier Reef as the world's MSP pilot plan, driven by conservation, evolved from the $80 \mathrm{~s}$ in the understanding of governance of marine spaces [41], till the recent updates of 2014. There seems to be an orientation in MSP education which is developed in Germany and Norway, associated to the combination of "environmental analysis and assessment" with "maritime sectors", which may find its origin in the drivers for MSP, related to the support of Blue Growth related to key maritime sectors, as renewable energy [71]. Only the case of Rhode Island demonstrates a balanced presence of all contents components, except for planning theory, as the course in "Maritime Affairs" is grounded in a long tradition in government and governance of marine spaces.

It is interesting to notice that stakeholder engagement is the least represented in terms of methods and tools. While several courses refer to stakeholder engagement in general, or at least refer to the governance dimension of managing marine waters, modules devoted to stakeholder engagement are very limited. Even if the interaction with social sciences for governance and stakeholder engagement are often deemed essential to MSP [72,73] and generally to the management of marine resources [49], from our analysis it seems that it is not formalised or recognised as a discipline within others, such as ecology or marine science, but more as a complementary subject related to the practice of MSP. This point can constitute a real barrier to MSP in terms of its transdisciplinary nature, which should be the result of a true integration between social sciences and marine sciences.

Finally, this analysis does not consider $\mathrm{PhD}$ level education. A wider analysis on $\mathrm{PhD}$ education would be necessary within the context of improving the theory and implementation of MSP. Along with our analysis, we have casually detected three $\mathrm{PhD}$ programmes: two of them report specifically on the topic of management of marine resources (Erasmus Mundus $\mathrm{PhD}$ in Water and Coastal Management, MACOMA; PhD programme in Marine science, technology and management "Do Mar") and are delivered by consortia of several HEI; the third one, the $\mathrm{PhD}$ in Marine Affairs of University or Rhode Island, is the only one that explicitly tackles the multidisciplinary requirements of MSP within the compulsory credits for $\mathrm{PhD}$ candidates, which encompass ocean uses and marine sciences, international ocean law, marine affairs seminar, economics of marine resources. The PhDs are indeed not specifically on MSP and related issues, but there are already many programmes involving some depth of knowledge in several fields, such as marine science and economics [48]. On the other hand, there are several individual $\mathrm{PhD}$ 
research projects that directly address MSP but that belong to $\mathrm{PhD}$ programmes framed in different disciplines, witnessing the need for a transdisciplinary contribution in order to found an MSP theory. Some examples can be found in the University of Wageningen (the Netherlands), the University of Ghent (Belgium), and the Bremen International Graduate School for Marine Science at Bremen University (Germany) ${ }^{10}$. While PhD education can contribute to the theoretical elaboration of MSP from multiple disciplines, the need for transdisciplinary education in MSP for profession and academia seems to emerge at the graduate-Master level, where it could effectively train professionals to respond to everyday challenges in MSP practice.

\section{Conclusions}

As part of raising attention surrounding MSP as an effective tool for planning and management of marine waters in a sustainable way [28], this paper proposes a first analysis of the current characteristics of education in MSP, both looking at tracing paths towards professional education, but also generating wider reflection on academic requirements in higher education. As emerging from the analysis, the educational offer is characterised by multiple combinations of content and method, which are generated by different interpretations of what MSP has been and what is now being practiced in Europe and in other countries.

We are aware that the reflection on education in MSP is currently undergoing rapid development, considering the establishment of new courses all around the world (for example Sweden, Canada, South Africa and the US). This analysis can be further expanded, as it is currently related to sampling chosen sample of countries, which has forced the authors to exclude countries that offer relevant courses related to MSP, such as, for example, France, Italy and Spain in Europe, but also in the US (Duke University, and Delaware University), or Canada (Dalhousie University). The value of this paper is to enhance a rigorous reflection on the theory behind MSP as transdisciplinary subject, which deserves specific attention in the debate of MSP [65] between scientists, experts and practitioners.

From our analysis, it seems to emerge that the current offer is established in continuity with ICM. However, there is a clear difference between MSP and ICM, which needs to be addressed in the educational provision, and that constitutes a challenge in educational offer in MSP in practice. Under European legislative framework, while ICM is mainly based on voluntary actions, MSP is statutory by its very nature [29]. It implies a strong revision in learning objectives related to MSP, to include the combined areas of maritime affairs and planning, among the other subjects. There is a risk of underestimating the governance level of MSP, in which the understanding and knowledge of Maritime Affairs and legal frameworks in relation to the definition of a "marine planning theory" are essential to defining the enforceability of MSplans, in line with that suggested by Barbanti et al. [74] and Jay et al. [70]. The issue of enforceability goes well beyond the

10 Examples at https://www.wageningenur.nl/en/show/Integrating-Ecosystem-Services-in-Marine-Spatial-PlanningPhD-project.htm [accessed 23.02.2016]); http://www.ugent.be/re/epir/en/researchgroups/public-internationallaw/research/phdresearch.htm, [accessed 23.02.2016]; http://www.uni-bremen.de/en/artec/research/theses-and-phdprojects.html [accessed 23.02.2016]. 
administrative fact of identifying the "MSP implementing authority" required by the Directive 2014/89/EU [4], but involves the structure of power organization and devolution.

Within this analysis, it was not possible to discuss on learning methods extensively because of the limitation in data availability according to the selected method. A deeper analysis and discussion of the learning methods required in planning and practiceoriented subjects such as MSP would be beneficial; starting, for example, with the recognised methods such as the Danish "Problem-Based Learning" (PBL) developed at the University of Aalborg [75], or simulation gaming for the understanding of MSP complexity [76].

Finally, it is important to reflect on how the educational provision in MSP is structured to reflect possible market and labor demands. While there is ongoing debate in relation to maritime educational provision and the labour market [77], for example, in the Baltic Region [78], it would be important to reflect on the educational profile of 'Marine Planners' with public administrations and other possible professions for job placement, looking at meeting the possible demand.

Marine spatial planning is substantially different from terrestrial planning $[70,79,80]$. Marine spatial plans must reflect the peculiar characteristics of highly dynamic marine environments in relation to multiple frameworks of the rights and duties of maritime sectors under the different legal statuses of maritime spaces. The challenge of the educational offer in MSP is to respond to the complexity of the transdisciplinary nature of MSP through a joint effort of disciplines, both for professionals and researchers.

\section{Acknowledgements}

This research has been financed under the support of the Erasmus Mundus Master Course on Maritime Spatial Planning (EMMCMSP), Contract no. 2013-0230. The authors would like to thank Francesco Musco (coordinator), Helena Calado, Ana Costa, Gema Gonzales of the Academic Board of the EMMCMSP, for discussing on topics and issues included in this paper along with the design, setting and implementation of the EMMCMSP; Tundi Agardy, for supporting the idea of the paper as a useful insight for students and practitioners in MSP; Ivana Lukic, for the support with courses data elaboration in Baltic countries; Vito Garramone, for the support in data analysis; the anonymous reviewers, for the comments which have helped to improve the paper.

\section{References}

[1] Commission of the European Communities, Green Paper, Towards a future Maritime Policy for the Union: A European vision for the oceans and seas [Brussels, 7.6.2006 COM(2006) 275 final, p. 34]

[2] UNESCO Intergovernamental Oceanografic Commission, Marine Spatial Planning Initiative, Marine Spatial Planning, http://www.unesco-iocmarinesp.be/marine_spatial_planning_msp [accessed 12.08.2015]

[3] UNESCO, Marine Spatial Planning Initiative, MSP Around the world, http://www.unescoioc marinesp.be/msp_around_the_world/united_states_rhode_island [accessed 12.08.2015] [4] European Parliament \& Council (EPC), Directive 2014/89/EU of the European Parliament and of the council of 23 July 2014 establishing a framework for maritime spatial planning, Off.J.Eur.Union L257 (2014) 135-145. 
[5] JL. Suárez de Vivero, JC. Rodríguez Mateos, and D Florido, Geopolitical factors of maritime policies and marine spatial planning: State, regions, and geographical planning scope. Marine Policy, 33 (2009) 624-634

[6] JL. Suárez de Vivero, JC. Rodríguez Mateos, Ocean governance in a competitive world. The BRIC countries as emerging maritime powers - building new geopolitical scenarios. Mar. Policy 34 (5) (2010) 967-978.

[7] C. Ehler, A guide to evaluating marine spatial plans, Paris, UNESCO. IOC Manuals and Guides, 70; ICAM Dossier 8, 2014.

[8] Convention on Biological Diversity. Marine Spatial Planning in Practice-Transitioning from Planning to Implementation. UNEP/CBD/SBSTTA/18INF/23, 18 June 2014.

[9] O. Vestergaard, Ecosystem-Based Marine Spatial Planning \& Management. UNEP-

DOALOS-FAO-WIOMSA Regional Training Course on Ecosystem-Based Marine Management, 27-31 October, 2008.

[10] H.G. Goodwin, J.G. Schaadt, The need for marine and aquatic education. In Disinger, J F

(Ed) Environmental education in Action VI: Change agents in and for environmental education.

ERIC Clearinghouse for Science, Mathematics, and Environmental Education, Columbus, Ohio: National Inst. of Education (ED), Washington, DC, 1982.

[11] University of Rhode Island, Marine Affairs Ph.D. Program, Graduate Programs, College of the Environment and Life Sciences, http://web.uri.edu/cels-gradprograms/marine-affairs-ph-dprogram/ [accessed 01.03.2016].

[12] University of Delaware, College of Earth, Ocean \& Environment, School of Marine

Science and Policy: Marine Policy Program, https://www.ceoe.udel.edu/schoolsdepartments/school-of-marine-science-and-policy/marine-policy [accessed 01.03.2016].

[13] Canadian Operational Centre of the International Ocean Institute, Elisabeth Mann Borgese, http://internationaloceaninstitute.dal.ca/emb.htm [accessed 01.03.2016].

[14] B. Cicin-Sain, R.W. Knecht, D. Jang, G.W. Fisk, Integrated coastal and ocean management: concepts and practices. Washington, Island Press, 1998.

[15] J.R. Clark, Integrated management of coastal zones. FAO Fisheries Technical Paper. No.

327. Rome, FAO. 1992. 167p. http://www.fao.org/docrep/003/t0708e/T0708E00.htm\#TOC

[accessed 01.03.2016].

[16] Organization for Economic Co-Operation and Development (OECD), Recommendation of the Council on Integrated Coastal Zone Management, 23 July 1992 - C(92)114/FINAL, $\mathrm{http} / /$ acts.oecd.org/Instruments/ShowInstrumentView.aspx?InstrumentID=42\&Lang=en\&Book $=$ False [accessed 01.03.2016].

[17] UNESCO-IHE, Institute for water education, https://www.unesco-ihe.org/integratedcoastal-zone-management) [accessed 01.03.2016].

[18] United Nations Environment Programme (UNEP), Regional Seas, Coastal Zone

Management, http://www.unep.org/regionalseas/issues/management/mngt/default.asp [accessed 01.03.2016].

[19] United Nations, Division for Ocean Affairs and the Law of the Sea (DOALOS), A cooperative training programme in the field of coastal and ocean management, TRAIN-SEA-

COAST Programme Office of Legal Affairs, United Nations, New York.

http://www.un.org/depts/los/tsc_new/TSCindex.htm [accessed 01.03.2016].

[20] World Bank, Integrated Coastal Zone Management,

http://www.worldbank.org/projects/P097985/integrated-coastal-zone-management?lang=en

[accessed 01.03.2016].

[21] World Health Organization (WHO), Integrated coastal zone management, health, and environment: directory of resources, Health and Environment Linkages Initiative (HELI), Priority environment and health risks,

http://www.who.int/heli/risks/water/coastalmanagement/en/index3.html [accessed 01.03.2016].

[22] European Commission, Integrated Coastal Management,

http://ec.europa.eu/environment/iczm/home.htm [accessed 01.03.2016]. 
[23] Rio+20. United Nations Conference on sustainable Development. The History of Sustainable Development in the United Nations, http://www.uncsd2012.org/history.html [accessed 18.08.2015].

[24] J. Wondolleck, S. Yaffee, Marine Ecosystem-Based Management in Practice (Ann Arbor MI: School of Natural Resources and Environment, University of Michigan, June 2012), www.snre.umich.edu/ecomgt/mebm. [accessed 18.08.2015].

[25] United Nations, Ocean \& Law of the sea, Division for Ocean Affairs and Law of the Sea. Ad Hoc Open-ended Informal Working Group to study issues relating to the conservation and sustainable use of marine biological diversity beyond areas of national jurisdiction, $\mathrm{http} / /$ www.un.org/depts/los/biodiversityworkinggroup/biodiversityworkinggroup.htm [accessed 18.08.2015].

[26] S. Davoudi, I. Strange, Space and place in Twentieth Century planning, An analytical framework and an historical review. In: S. Davoudi, I. Strange (Eds.). Conceptions of space and place in strategic spatial planning. THE RTPI Library Series 17. Routledge. London and New York, 2008, ISBN 0-203-88650-X, p. 7-42.

[27] UNEP \& GEF-STAP, 2014, Marine spatial planning in practice, transitioning from planning to implementation. UNEP/CBD/SBSTTA/18/INF/23. 18 June 2014.

https://www.cbd.int/doc/meetings/sbstta/sbstta-18/information/sbstta-18-inf-23-en.pdf [accessed 01.03.2016].

[28] Ehler C, Douvere F. Marine spatial planning: a step-by-step approach toward ecosystembased management. Intergovernmental Oceanographic Commission Manual and Guides No. 53, ICAM Dossier no. 6. Paris: UNESCO; 2009.

http://unesdoc.unesco.org/images/0018/001865/186559e.pdf

[29] G. Glegg, Training for marine planners: Present and future needs. Mar. Policy, 43 (2014) $13-20$.

[30] T. Derudder, F. Maes. Marine Spatial Planning and the Protection of the Marine Environment in the Belgian Part of the North Sea. Country report. (2015) IUCNAEL EJOURNAL. p.144-154, http://hdl.handle.net/1854/LU-5984286 [accessed 01.03.2016]. [31] HELCOM, EU strategy for Baltic sea region, Horizontal Action Spatial Planning, http:/helcom.fi/action-areas/maritime-spatial-planning/horizontal-action-spatial-planning/ [accessed 01.03.2016].

[32] H. Calado, K. Ng, D. Johnson, L. Sousa, M. Phillips, F. Alves, Marine spatial planning: lessons learned from the Portuguese debate. Mar. Policy, 34(6) (2010) 1341-1349.

[33] H. Calado, J. Bentz, The Portuguese maritime spatial plan. Mar. Policy, 42 (2013) 325-333. [34] V. Becker-Weinberg, Portugal's legal regime on marine spatial planning and management of the national maritime space. Mar. Policy 61 (2015) 46-53.

[35] Direcao-Geral de Politica do Mar (dgpm). Regime Jurídico do Ordenamento e Gestão do Espaço Marítimo Nacional,

http://www.dgpm.mam.gov.pt/Pages/POEM_PlanoDeOrdenamentoDoEspacoMarinho.aspx, [accessed 01.03.2016].

[36] Marine Management Organization and Planning Inspectorate, Marine Planning, https://www.gov.uk/topic/planning-development/marine-planning, [01.03.2016].

[37] G. Scarff, C. Fitzsimmons, T. Gray, The new mode of marine planning in the UK:

Aspirations and challenges. Mar. Policy 51 (2015) 96-102.

[38] J. Day, The need and practice of monitoring, evaluating and adapting marine planning and management-lessons from the Great Barrier Reef. Mar. Policy 32(5) (2008) 823-831.

[39] Australian Government, Department of the Environment, Coral Sea Commonwealth Marine Reserve, https://www.environment.gov.au/topics/marine/marine-reserves/coral-sea/ [accessed 01.03.2016].

[40] P. Monteiro, T. de Noronha, P. Neto, A differentiation framework for maritime clusters: Comparisons across Europe, Sustainability, 5(9) (2013) 4076-4105.

[41] J.C. Day, Zoning - lessons from the Great Barrier Reef Marine Park. Ocean Coast. Manage. 45 (2002) 139-156. 
[42] A. Chircop, Teaching integrated coastal management: lessons from the learning arena. Ocean Coast. Manage. 43 (2000) 343-59.

[43] H.D. Smith, Education and training for integrated coastal area management: the role of the university system. Ocean Coast. Manage. 43 (2000) 379-87.

[44] S. Fletcher, Empowering learning through design: a comparative analysis of ICM course development for web-based and classroom delivery, Mar. Policy 25 (2001) 457-466.

[45] M. Garriga, I.J. Losada, Education and training for integrated coastal zone management in Europe. Ocean Coast. Manage. 53(3) (2010) 89-98.

[46] M .Hunsicker, L. Ciannelli, J. M. Anderies et al., Multi-disciplinary higher education is critical for marine ecosystem sustainability, Ecological society of America, 2012

$\mathrm{http} / / / \mathrm{www}$.marineresearchnetwork.org/wp-

content/uploads/2012/11/HunsickerEtAl_ESA2012.Web_.pdf [accessed 01.03.2016].

[47] J.L. Blickley, K. Deiner, K. Garbach et al., Graduate student's guide to necessary skills for nonacademic conservation careers, Conserv. Biol. 27(1) (2013) 24-34.

[48] L. Ciannelli, M. Hunsicker, A. Beaudreau, et al., Transdisciplinary graduate education in marine resource science and management. ICES Journal of Marine Science: Journal du Conseil, fsu067, 2014.

[49] B. Paterson, M. Isaacs, M. Hara, A. Jarre, C.L. Moloney, Transdisciplinary co-operation for an ecosystem approach to fisheries: a case study from the South African sardine fishery. Mar. Policy, 34(4) (2010) 782-794.

[50] I. Galparsoro, P. Liria, I. Legorburu, J. Bald, G. Chust, P. Ruiz-Minguela, G. Pérez, et al., A marine spatial planning approach to select suitable areas for installing wave energy converters (WECs), on the Basque Continental Shelf (Bay of Biscay). Coast. Manage. 40 (2012) 1-19.

[51] K. Bonine, J. Reid, R. Dalzen. Training and education for tropical conservation. Conser. Biol. 17 (2003) 1209-1218.

[52] H.M. Leslie, A Synthesis of Marine Conservation Planning Approaches. Conser. Biol. 19 (2005) 1701-1713. doi: 10.1111/j.1523-1739.2005.00268.x.

[53] K.A. Wilson, E. Underwood, S. Morrison, K. Klausmeyer, W. Murdoch, et al., Conserving biodiversity efficiently: what to do, where and when, PLoS Biol 5(9) (2007) e223.

[54] E.M. Olsen, D. Johnson, P. Weaver, R. Goñi, M.C. Ribeiro, M. Rabaut, E. Macpherson, D. Pelletier, L. Fonseca, S. Katsanevakis, T. Zaharia, Achieving Ecologically Coherent MPA Networks in Europe: Science Needs and Priorities. Marine Board Position Paper 18. Larkin, KE and McDonough N (Eds.). European Marine Board, Ostend, Belgium, 2013,

http://www.esf.org/fileadmin/Public_documents/Publications/EMB_PP18_Marine_Protected_A reas.pdf [accessed 01.03.2016].

[55] F. Douvere, The importance of marine spatial planning in advancing ecosystem-based sea use management, Mar. Policy 32(5) (2008) 762-771.

[56] P.K. Dunstan, N.J. Bax, J.M. Dambacher, K.R. Hayes, P.T. Hedge, D.C. Smith, A.D. Smith, Using ecologically or biologically significant marine areas (EBSAs) to implement marine spatial planning, Ocean Coast. Manage. 121 (2016) 116-127.

[57] I.R. Ball, H.P. Possingham, Marxan (v. 1.8.6): Marine Reserve Design Using Spatially Explicit Annealing. User Manual, 2000, http://www.uq.edu.au/marxan.

[58] H.P. Possingham, I.R. Ball, S. Andelman, Mathematical methods for identifying representative reserve networks. In: Ferson, S., Burgman, M. (Eds.), Quantitative Methods for Conservation Biology. Springer-Verlag, New York, 2000, 291-305.

[59] H.P. Possingham, K.A. Wilson, S.J. Andelman, C.H. Vynne, Protected areas: goals, limitations, and design. In: Groom, M.J., Meffe, G.K., Carroll, C.R. (Eds.), Principles of Conservation Biology, third ed. Sinauer Associates Inc., Sunderland, MA, 2006, 509-533. [60] Watts, M. E., Ball, I. R., Stewart, R. S., Klein, C. J., Wilson, K., Steinback, C., ... \& Possingham, H. P. (2009). MARXAN with Zones: software for optimal conservation based land-and sea-use zoning. Environmental Modelling \& Software, 24(12), 1513-1521.

[61] M.E. Watts, C.J. Klein, R.R. Stewart, I.R. Ball, H.P. Possingham, Marxan with Zones (V1.0.1): Conservation Zoning Using Spatially Explicit Annealing, a Manual. University of Queensland, Brisbane, 2008, http://www.uq.edu.au/marxan. 
[62] A. Moilanen, K.A. Wilson, H.P. Possingham, Spatial Conservation Prioritization: Quantitative Methods and Computational Tools. Oxford University Press, Oxford, 2009.

[63] R.A. Kenchington, J.C. Day, Zoning, a fundamental cornerstone of effective Marine Spatial Planning: lessons learnt from the Great Barrier Reef, Australia, J. Coast. Conserv. 15(2) (2011) 271-278.

[64] T. Agardy, Marine Protected Areas and Marine Spatial Planning, In Routledge Handbook of Ocean Resources and Management Hance D. Smith, J. L. Suárez de Vivero, T. S. Agardy (Eds), Routledge, Oxon/New York, 2015, 476-492.

[65] S. Kidd \& G. Ellis (2012) From the Land to Sea and Back Again? Using Terrestrial Planning to Understand the Process of Marine Spatial Planning, J. Environ. Pol. Plan. 14:1, 4966, DOI: 10.1080/1523908X.2012.662382.

[66] G. Scarff, C. Fitzsimmons, T. Gray, The new mode of marine planning in the UK: Aspirations and challenges. Mar. Policy 51 (2015) 96-102.

[67] D. Smith, J. L. Suárez de Vivero, T. S. Agardy (Eds), Routledge Handbook of Ocean Resources and Management Hance, Routledge, Oxon/New York, 2015, pp. 611.

[68] Interdepartemantal Co-ordinating Committee for North Sea Affairs (ICONA), North Sea Atlas for Netherlands policy and management, Stadsuitgeverij, Amsterdam, 1992.

[69] S.J. Boyes, M. Elliott. The excessive complexity of national marine governance systemsHas this decreased in England since the introduction of the Marine and Coastal Access Act 2009? Mar. Policy 51 (2015) 57-65.

[70] S. Jay, F.L. Alves, C. O'Mahony, et al., Transboundary dimensions of marine spatial planning: Fostering inter-jurisdictional relations and governance. Mar. Policy 65 (2016) 85-96. [71] W. Qiu, P.J.S. Jones, The emerging policy landscape for marine spatial planning in Europe, Mar. Policy, 39 (2013) 182-190.

[72] R. Pomeroy, F. Douvere, The engagement of stakeholders in the marine spatial planning process, Mar. Policy 32 (5) (2008) 816-822, http://dx.doi.org/10.1016/j.marpol.2008.03.017.

[73] H. Ritchie, G. Ellis, A system that works for the sea'? Exploring stakeholder engagement in marine spatial planning, J. Environ. Plan. Manag., 53 (6) (2010) 701-723.

[74] A. Barbanti, P. Campostrini, F. Musco, A. Sarretta, E. Gissi (Eds), Developing a Maritime Spatial Plan for the Adriatic-Ionian Region. CNR-ISMAR, Venice, 2015.

[75] T. Ryberg, B. Nørgaard, Introducing Problem Based Learning in Higher Education, Journal of Problem Based Learning in Higher Education, 1(1) (2013) I-VI.

[76] I. Mayer, Q. Zhou, J. Lo, L. Abspoel, X. Keijser, E. Olsen, E. Nixon, A. Kannen, Integrated, ecosystem-based Marine Spatial Planning: Design and results of a game-based, quasi-experiment, Ocean Coast Manage, 82 (2013) 7-26.

[77] J. Ho, K.Y.A. Ng, A. Koo, The added-values and motivations of embarking on postgraduate maritime studies, Proceedings of International Forum on Shipping, Ports and Airports, IFSPA 2008 - Trade-Based Global Supply Chain and Transport Logistics Hubs: Trends and Future Development, 2008.

[78] Multiple Authors, Foresight of the South Baltic maritime labour market 2017, http://www.generationbalt.eu/data/user/documents/Foresight_Maritime_Labour_Market_South Balt.pdf. [accessed 01.03.2016].

[79] M. Foley, B. Halpern, F. Micheli, et al., Guiding ecological principles for marine spatial planning, Mar. Policy 34 (2010) 955-966.

[80] J. Zaucha, Sea basin maritime spatial planning: a case study of the Baltic Sea region and Poland, Mar. Policy, 50 (2014), pp. 34-45. 